\title{
PENGARUH BRAND IMAGE TERHADAP MOTIVASI DAN MINAT WISATAWAN DOMESTIK BERKUNJUNG KE SANUR VILLAGE FESTIVAL
}

\author{
I Gusti Putu Pandu Fariska ${ }^{1}$ I Gusti Putu Bagus Sasrawan Mananda ${ }^{2}$, \\ Ni Gusti Ayu Susrami Dewi ${ }^{3}$ \\ ${ }^{1}$ Email: gunkpandu3@gmail.com \\ Program Studi Industri Perjalanan Wisata, Fakultas Pariwisata, Universitas Udayana \\ ${ }^{2}$ Email: gusmananda@unud.ac.id \\ Program Studi Industri Perjalanan Wisata, Fakultas Pariwisata, Universitas Udayana \\ ${ }^{3}$ Email: susrami_ipw@unud.ac.id \\ Program Studi Industri Perjalanan Wisata, Fakultas Pariwisata, Universitas Udayana
}

\begin{abstract}
Sanur Village Festival is an event established by the Yayasan Pembangunan Sanur which combines large-scale activities consisting of food festivals, a series of contests, competitions, cultural arts attractions, music, and a variety of friendly activities environment. Samples of this study were domestic tourists who have visited the Sanur Village Festival. The sampling technique used purposive sampling in 160 respondents. Data collection techniques are performed with observations, questionnaires, interviews, literature studies, and documentation. The sampling technique uses the purposive sampling technique and utilizes a likert scale model questionnaire that is calibrated using the validity test and the reliability test is calculated using the Cronbach alpha coefficient using the SPSS 25.0. The data analysis techniques in this study used partial least square analysis techniques (PLS), and the equation model will analyzed is the outer model, inner model and hypotheses testing. Based on the software calculation smartPLS version 3.0 obtained the result that there is a significant influence between the variable brand image to the motivation and interest of domestic tourists visit to Sanur Village Festival. This is evidenced by the results of the analysis of the influence of the brand image to the motivation obtained value of $41.9 \%$, while the interest earned a value of $40.5 \%$. Furthermore, the influence of motivation to interest can be seen from the results of the analysis of Partial Least Square obtained T-Statistic of $1.766>$ T-table 1.654, this means the motivation variable positively affect the interest of domestic tourists visiting Sanur Village Festival.
\end{abstract}

\begin{abstract}
Abstrak: Sanur Village Festival adalah acara yang didirikan oleh Yayasan Pengembangan Sanur yang menggabungkan kegiatan berskala besar yang terdiri atas festival makanan, serangkaian kontes, kompetisi, atraksi seni budaya, musik, serta berbagai kegiatan ramah lingkungan. Sampel yang digunakan adalah wisatawan domestik yang pernah berkunjung ke Sanur Village Festival. Teknik penentuan sampel menggunakan purposive sampling pada 160 orang responden. Teknik pengumpulan data dilakukan dengan observasi, kuesioner, wawancara, studi kepustakaan, dan dokumentasi. Teknik penentuan sampel menggunakan teknik purposive sampling dan menggunakan kuesioner model skala likert yang dikalibrasikan dengan memakai uji validitas dan uji reliabilitas dihitung dengan memakai koefisien alpha cronbach dengan menggunakan SPSS 25.0. Teknik analisis data dalam penelitian ini menggunakan teknik analisis partial least square (PLS), dengan model persamaan dianalisis adalah model bagian luar (outer model), model bagian dalam (inner model) dan pengujian hipotesis. Berdasarkan penghitungan perangkat lunak smartPLS versi 3.0 diperoleh hasil bahwa terdapat pengaruh signifikan antara variabel brand image terhadap motivasi dan minat wisatawan domestik berkunjung ke Sanur Village Festival. Hal ini dibuktikan dari hasil analisis determinasi pengaruh brand image terhadap motivasi diperoleh nilai sebesar $41,9 \%$, sedangkan pada minat diperoleh nilai sebesar 40,5\%. Selanjutnya pengaruh motivasi terhadap minat dapat dilihat dari hasil analisis Partial Least Square diperoleh t-statistic sebesar 1,766 > t-Tabel 1,654, hal ini berarti variabel motivasi berpengaruh positif terhadap minat wisatawan domestik berkunjung ke Sanur Village Festival.
\end{abstract}

Keywords: brand image, motivation, interests, sanur village festival. 


\section{PENDAHULUAN}

Indonesia sebagai negara berkembang merupakan salah satu negara yang begitu giat dalam membangun sektor ekonomi. Selain memiliki potensi yang besar dalam perut bumi seperti minyak bumi, gas alam, batubara dan lain-lain, Indonesia juga memiliki potensi yang begitu besar dalam pengembangan sektor pariwisatanya. Ragam budaya, keindahan alam merupakan faktor atau aset yang yang berharga dalam pengembangan pariwisatanya.

Bali merupakan salah satu provinsi di Indonesia yang begitu gencar dalam mengembangkan pariwisatanya. Bali sudah tidak dapat dipisahkan lagi dengan pariwisata sejak beberapa dasawarsa terakhir, bahkan sejak dasawarsa awal abad ini. Selain kebudayaan, Bali memiliki panorama alam yang indah. Salah satu daya tarik wisata alam yang terkenal di Bali adalah Pantai Sanur. Sanur yang merupakan salah satu kawasan pariwisata tertua di Bali yang pertama kalinya memiliki resort, Sanur mulai dikunjungi sejak tahun 1930an. Sanur merupakan salah satu ikon pariwisata Bali yang sudah dikenal sejak 80 tahun yang lalu hingga sekarang. Sanur sebagai resort tourism yang dikembangkan secara khusus untuk mendatangkan tourist (wisatawan asing) yang tergolong kelompok wisatawan elit dari Negara asalnya.

Sanur dengan berbagai keunikan tradisi, kelembagaan, serta keindahannya merupakan kekayaan yang menjadi daya pikat bagi setiap orang, tidak saja bagi masyarakat Sanur, Bali, bahkan duniapun mengakuinya. Keindahan dapat kita nikmati mulai pagi hari dengan matahari terbitnya, siangnya dengan berbagai aktifitas masyarakatnya dan malam dengan deburan ombak, semilir angin pantai dan sinar bulannya. Akibatnya Sanur mengalami perkembangan dan pertumbuhan dari berbagai sektor yang sangat pesat. Desa Sanur telah mengalami transformasi dari desa nelayan menjadi desa yang menggantungkan diri pada sektor pariwisata.

Sanur memiliki atraksi wisata, sarana transportasi (mudah di akses), sarana akomodasi, dan juga fasilitas pendukung lainnya yang dibutuhkan dalam pengembangan pariwisata. Wilayah ini memiliki potensi yang sangat besar dalam meningkatkan taraf hidup masyarakat sekitar dan menyumbang pajak untuk pembangunan Bali. Sanur dapat menjadi tempat yang ideal untuk liburan di Bali. Suasana pesisir pantai yang unik menjadi identifikasi Sanur di mana industri pariwisata menyatu harmonis bersama keseharian masyarakat terutama dengan tradisi-tradisi budaya Bali. Setiap sudut Desa menyediakan eksplorasi tertentu untuk setiap pengunjung. Barisan pepohonan yang teduh di sepanjang jalan, hamparan pantai untuk berjemur, barisan toko-toko untuk berbelanja dan berbagai restoran, memberikan pilihan yang tidak ada habisnya di Sanur. Jumlah wisatawan yang berkunjung ke Sanur mengalami peningkatan, jumlah pengunjung yang tertinggi pada tahun 2017 dengan jumlah pertumbuhan 0,105\%. Pada tahun 2018 mengalami penurunan yang signifikan dengan jumlah pertumbuhan $-0,191 \%$, hal ini disebabkan karena pasca erupsi Gunung Agung setahun lalu yang menyebabkan penurunan kunjungan wisatawan ke Bali.

Kawasan Sanur termasuk salah satu kawasan strategis pariwisata nasional (KSPN) yang ada di Bali. Kehadiran KSPN ini merupakan kebijaksanaan pemerintah pusat yang berkaitan regulasi pengembangan maupun penataan wisata diseluruh tanah air. Lewat KSPN ini pemerintah pusat sudah memberikan rambu-rambu tentang penentuan kawasan wisata yang dipandang strategis secara nasional sebagai daya tarik wisata, sehingga menjadi daya tarik bagi wisatawan. Hanya saja potensi ini yang dimiliki oleh masyarakat Sanur termasuk daerah Bali lainnya untuk digarap secara inovatif dan lebih kreatif. Kawasan wisata Sanur memiliki dua potensi yang dapat menopang sektor pariwisata, yaitu wisata bahari dan wisata budaya. Jumlah wisatawan domestik yang berkunjung ke Sanur mengalami penurunan, jumlah pengunjung yang tertinggi pada tahun 2014. Pada tahun 2015 sampai tahun 2018 mengalami penurunan yang signifikan, hal ini disebabkan karena adanya pilihan alternatif daya tarik wisata di Bali selain Sanur seperti Kuta, Ubud dan Nusa Dua. Maka penting perlu diadakannya sebuah acara untuk mendongkrak kunjungan wisatawan domestik ke Sanur seperti Sanur Village Festival.

Sanur Village Festival (SVF) merupakan salah satu aktivitas pariwisata yang dikemas dalam bentuk festival untuk membangkitkan kembali citra pariwisata di daerah ini yang sempat terpuruk sebagai dampak dari peristiwa bom Bali I (2002) dan bom Bali II (2006) di masa lalu. Kegiatan ini diselenggarakan setiap satu tahun sekali. 
Sanur Village Festival (SVF) didukung oleh tiga desa dinas, yaitu Kelurahan Sanur sebagai desa induk, Desa Sanur Kauh, dan Desa Sanur Kaja. Sebelum terjadi perkembangan, masyarakat lebih mengenal dengan Desa Sanur sekaligus dengan kawasan daya tarik wisata yang sangat terkenal yaitu pantai Sanur. Kemudian, pantai Sanur dalam perkembangannya dewasa ini sudah mendunia. Artinya, hampir seluruh wisatawan dari berbagai belahan dunia pernah melakukan kunjungan ke kawasan wisata sanur. Sanur Village Festival dilandasi oleh visi dan misi untuk menarik simpati wisatawan untuk berkunjung ke kawasan wisata Sanur. Hal ini didukung oleh hasil wawancara kepada Putu Suanta selaku sekretaris umum Yayasan Pembangunan Sanur mengenai kunjungan wisatawan domestik ke Sanur Village Festival, dimana wisatawan domestik yang berkunjung ke Sanur Village Festival selalu meningkat setiap tahunnya, jumlah pengunjung yang tertinggi pada tahun 2019 dengan jumlah pertumbuhan $0,130 \%$. Pada tahun 2018 mengalami peningkatan yang signifikan dengan jumlah pertumbuhan $0,369 \%$, hal ini disebabkan karena tempat diselenggarakannya Sanur Village Festival pada tahun sebelumnya diseleggarakan di Maisonnette Area Inna Grand Bali Beach Sanur yang memiliki luas sekitar $\pm 17.503 \mathrm{~m}^{2}$ sedangkan mulai tahun 2018 lalu yang diselenggarakan di Pantai Matahari Terbit yang memiliki area lebih luas dari Maisonnette Area Inna Grand Bali Beach Sanur yaitu sekitar $\pm 35.223 \mathrm{~m}^{2}$.

Menurut Kotler (2002), Brand image merupakan sekumpulan asosiasi merek yang terbentuk dan melekat di benak konsumen. Brand image yang dimiliki kawasan Sanur yaitu Sanur Village yang kemudian potensi potensi yang dimiliki oleh Desa Sanur disatukan pada Sanur Village Festival (SVF) dengan menyatukan potensi - potensi yang dimiliki oleh Desa Sanur dalam sebuah acara kegiatan yang menjadi salah satu bentuk kegiatan untuk mempromosikan budaya lokal berhasil dilakukan oleh masyarakat lokal juga.

Minat berkunjung wisatawan biasanya muncul karena adanya persepsi positif terhadap daya tarik wisata. Kinnear dan Taylor (dalam Arumni, 2013) menyatakan bahwa minat berkunjung adalah tahap kecenderungan responden untuk bertindak sebelum keputusan berkunjung benar-benar dilaksanakan. Alasan-alasan yang digunakan untuk melakukan perjalanan wisata pun beragam, mulai dari menghilangkan penat dari perkerjaan atau kegiatan sehari-hari, hingga melakukan perjalanan wisata untuk berkumpul bersama keluarga. Banyak faktor yang memotivasi orang untuk melakukan perjalanan wisata. Menurut Moutinho (dalam Lay, 2014), motivasi adalah keadaan membutuhkan, suatu kondisi yang memberikan sebuah dorongan pada individu terhadap beberapa jenis tindakan yang dipandang sebagai kemungkinan untuk membawa kepuasan. Dann (dalam Verain, 2015), motivasi wisata adalah keadaan pikiran yang cukup menentukan keputusan seseorang, atau kelompok untuk berwisata, yang kemudian ditafsirkan oleh orang lain sebagai penjelasan yang valid untuk keputusan tersebut.

Melalui penelitian ini diharapkan mampu mengetahui bagaimana pengaruh brand image dari Sanur Village Festival terhadap motivasi dan minat wisatawan domestik yang berkunjung ke Sanur Village Festival. Hal ini yang mendasari peneliti tertarik untuk melakukan penelitian terkait dengan pengaruh brand image terhadap motivasi dan minat wisatawan domestik berkunjung ke Sanur Village Festival.

\section{METODE PENELITIAN}

Penelitian ini dilakukan di Desa Sanur, Denpasar Selatan, Bali. Jarak Sanur Village Festival dari Denpasar sekitar $7 \mathrm{~km}$ dengan waktu tempuh sekitar 15 menit. Sanur Village Festival adalah pesta rakyat masyarakat tahunan yang diselanggarakan oleh Yayasan Pembangunan Sanur. Variabel yang digunakan berdasarkan teori brand image, motivasi (push and pull factor), dan minat. Teknik pengumpulan data dilakukan dengan observasi, kuesioner, wawancara, studi kepustakaan, dan dokumentasi. Teknik pengambilan sampel dilakukan dengan purposive sampling. Teknik penentuan sampel menggunakan purposive sampling pada 160 orang responden. Teknik pengumpulan data dilakukan dengan observasi, kuesioner, wawancara, studi kepustakaan, dan dokumentasi. Teknik penentuan sampel menggunakan teknik purposive sampling dan menggunakan kuesioner model skala likert yang dikalibrasikan dengan memakai uji validitas dan uji reliabilitas dihitung dengan memakai koefisien alpha cronbach dengan 
menggunakan SPSS 25.0. Teknik analisis data dalam penelitian ini menggunakan teknik analisis partial least square (PLS), dengan model persamaan dianalisis adalah model bagian luar (outer model), model bagian dalam (inner model) dan pengujian hipotesis.

\section{HASIL DAN PEMBAHASAN Gambaran Umum Sanur Village Festival}

Sanur Village Festival adalah acara komunitas yang didirikan oleh Yayasan Pengembangan Sanur (YPS), yang menggabungkan kegiatan berskala besar yang melibatkan festival makanan, pameran ekonomi kreatif, serangkaian kontes dan kompetisi, atraksi seni dan budaya, musik, serta berbagai kegiatan yang ramah lingkungan. Sanur Village Festival sudah diadakan selama 13 kali dan tahun ini adalah yang ke-14 diselenggarakan pada tanggal 2125 Agustus 2019 dengan tema "Dharmaning Gesing”. Tema ini diangkat dari kesadaran dan penghargaan akan peranan bambu dalam kehidupan masyarakat Bali sehari-hari. Seperti diketahui hampir di setiap upacara keagamaan, bambu pasti digunakan, baik daun maupun batangnya. Bambu menjadi salah satu bagian bangunan adat di Bali. Tema "Dharmaning Gesing" dapat diartikan secara harafiah sebagai hal untuk memuliakan atau kewajiban berbuat baik kepada bambu. Tanaman bambu menjadi bahasan kesadaran filosofi bambu di Bali. Bambu merupakan salah satu jenis tanaman yang paling banyak digunakan mayarakat Bali dalam kehidupan sehari-hari. Hampir di setiap upacara keagamaan, bambu pasti digunakan, baik daun maupun batangnya. Bambu juga menjadi salah satu unsur penting bangunan arsitekur adat Bali. Bagi masyarakat Bali, bambu memang memiliki filosofi kuat dan sangat mendalam.

Logo dari Sanur Village Festival dimana berbentuk bulatan dengan berbagai macam kegiatan yang memiliki arti semangat tinggi masyarakat dalam membangun Desa Sanur dengan beragam kreativitas masyarakat dalam sebentuk festival. Pada logo dilengkapi dengan tagline Fun and Cultural Event. Logo ini diposisikan mengikuti lekukan simbol kepala "jukung" khas Sanur "Gajah Mina". Sebagai bingkai kegiatan seluruh simbol aktivitas diletakkan dalam lingkaran yang menggambarkan matahari terbit. Kehadiran matahari terbit diartikan sebagai semangat atau kekuatan yang menyinari bumi dan masyarakat Sanur yang tidak pernah berhenti. Kaitannya dalam brand image yang diteliti dalam penelitian ini yaitu kreativitas Yayasan Pembangunan Sanur dalam menggelar berbagai jenis kegiatan yang melibatkan masyarakat lokal dalam sebuah acara yang bertujuan untuk mengembalikan citra Bali yang sempat terpuruk saat peristiwa bom Bali I dan II pada tahun 2005 lalu.

Perayaan tahunan ini dirancang dan dimotori oleh Ida Bagus Sidartha Putra bersama insan pariwisata, seni dan budaya yang selanjutnya menjadi sebuah festival dan dijalankan sepenuhnya oleh Yayasan Pembangunan Sanur. Dihelat di tepi Pantai Sanur, festival itu kemudian lahir dengan nama Sanur Village Festiaval atau lebih dikenal dengan SVF atau Sanfest. Tercatat tiga tempat yang telah menjadi tempat ajang SVF yakni kawasan Maesonette Area di Inna Grand Bali Beach, Pantai Mertasari dan Pantai Matahari Terbit, Sanur. Konsep Sanur Village Festival sebagai ruang kreativitas sekaligus koridor antara kehidupan masyarakat, seni dan budaya. Selanjutnya konsep ini diterjemahkan secara mengalir dan kontekstual dalam industri pariwisata dengan semangat baru menjalankan warisan leluhur yaitu The New Spirit of Heritage.

\section{Karakteristik Wisatawan Domestik yang Berkunjung ke Sanur Village Festival}

Responden dalam penelitian ini adalah wisatawan domestik yang pernah berkunjung ke Sanur Village Festival. Kuesioner dalam penelitian ini disebarkan kepada wisatawan domestik. Jumlah responden yang digunakan dalam penelitian ini adalah sebanyak 160 orang. Adapun karakteristik tersebut dikelompokkan menurut umur, jenis kelamin, daerah asal, pendidikan terakhir, status pekerjaan, frekuensi kunjungan ke Bali, frekuensi kunjungan ke SVF, hal yang disukai di SVF (Pitana dan Gayatri, 2005).

Karakteristik responden wisatawan domestik yang berkunjung ke Sanur Village Festival didominasi oleh kelompok usia 21-30 tahun dan jika ditinjau dari jenis kelamin, sebagian besar memiliki jenis kelamin lakilaki. Wisatawan domestik yang berkunjung sebagian besar berasal dari Jawa Barat dengan mayoritas memiliki status pendidikan terakhir SMA/sederajat. Status pekerjaan wisatawan yang berkunjung didominasi oleh pelajar, dengan frekuensi telah mengunjungi bali 
sejumlah 1 sampai 3 kali. Sedangkan karakteristik responden berdasarkan frekuensi mengunjungi Sanur Village Festival dalam penelitian ini didominasi dengan frekuensi 1-3 kali dikarenakan Sanur Village Festival memiliki berbagai macam tema yang berbedabeda dan menarik setiap tahunnya, sehingga wisatawan tertarik untuk datang setiap tahunnya. Dilihat dari sumber informasi mengenai Sanur Village Festival dalam penelitian ini didominasi bersumber informasi dari media sosial, hal tersebut terjadi dikarenakan Sanur Village Festival memiliki beberapa akun media sosial yang aktif seperti Instagram, Facebook dan Twitter. Sebagian besar wisatawan yang berkunjung menyukai parade/atraksi kesenian dari Sanur Village Festival, hal tersebut terjadi dikarenakan Sanur Village Festival memiliki beragam jenis parade/atraksi kesenian dari Desa Sanur itu sendiri yang biasanya disemarakkan dengan berbagai garapan seni tradisi maupun modern.

\section{Persepsi Wisatawan Domestik Mengenai Brand Image Terhadap Motivasi dan Minat Berkunjung ke Sanur Village Festival \\ Skor rata-rata persepsi wisatawan} terhadap variabel brand image dengan jumlah responden sebanyak 160 responden. Adapun 3 dimensi variabel yaitu kekuatan (strenght), keunikan (uniqueness), serta berkenan (favourable) yang didalamnya terdapat 10 pernyataan yang menyatakan bahwa untuk rata-rata skor variabel brand image adalah sebesar 3,79 dalam kategori setuju. Dalam hal ini dimensi variabel kekuatan (strenght) yang didalamnya terdapat pengemasan festival yang menarik dan inovatif yang mendominasi dengan skor rata-rata 4,01, hal ini membuktikan bahwa Sanur Village Festival selalu memberikan acara yang menarik seriap tahunnya serta dikemas secara inovatif sehingga menjadi kekuatan dari Sanur Village Festival itu sendiri. Untuk pernyataan yang lain masing-masing mendapatkan nilai skor 3,86 untuk pernyataan lokasi festival yang mudah dijangkau, nilai skor rata rata sebesar 3,93 untuk pernyataan produk yang ditawarkan saat festival bervariasi, nilai skor rata rata sebesar 3,26 untuk pernyataan Sanur Village Festival merupakan satu-satunya festival yang diselanggarakan di Sanur, nilai skor rata rata sebesar 3,98 untuk pernyataan keunikan atraksi wisata yang ditampilkan.
Rata-rata persepsi wisatawan terhadap variabel motivasi dengan jumlah responden sebanyak 160 responden. Adapun 9 dimensi variabel yaitu relaksasi, bermain, gengsi, romantis, budaya, mewujudkan mimpi, atraksi, promosi, waktu yang didalamnya terdapat 14 pernyataan yang menyatakan bahwa untuk rata-rata skor variabel adalah sebesar 3,77 dalam kategori setuju. Dalam hal ini dimensi variabel motivasi yang didalamnya terdapat Sanur Village Festival diselenggarakan bertepatan dengan waktu liburan yang mendominasi dengan skor rata-rata 4,12. Hal ini dikarenakan Sanur Village Festival diadakan bulan agustus dimana puncak acara biasanya pada hari sabtu dan minggu bertepatan pada waktu liburan untuk wisatawan yang berstatus pelajar dimana hal tersebut sesuai dengan karakteristik berdasarkan status pekerjaan sebagai pelajar yang mendominasi dari status pekerjaan lainnya. Untuk pernyataan yang lain masingmasing mendapatkan nilai skor 3,70 untuk pernyataan mengunjungi Sanur Village Festival untuk keluar dari rutinitas seharihari/relaksasi, nilai skor rata rata sebesar 3,95 untuk pernyataan mengunjungi Sanur Village Festival untuk bersenang-senang, nilai skor rata rata sebesar 3,47 untuk pernyataan mengunjungi Sanur Village Festival untuk menunjukkan gengsi, nilai skor rata rata sebesar 3,66 untuk pernyataan mengunjungi Sanur Village Festival bersama orang yang bisa memberikan suasana romantis.

Skor rata-rata persepsi wisatawan terhadap variabel minat berkunjung dengan jumlah responden sebanyak 160 responden. Yang mana terdapat 4 dimensi variabel yaitu minat transaksional, minat referensial, minat preferensial, minat eksploratif yang didalamnya terdapat 8 pernyataan yang menyatakan bahwa untuk rata-rata skor variabel adalah sebesar 3,91 dalam kategori setuju. Dalam hal ini dimensi variabel minat berkunjung yang didalamnya terdapat mencari tahu pengalaman kunjungan ke festival melalui sosial media dimiliki dengan skor ratarata 4,10 , hal ini membuktikan bahwa hampir semua responden yang akan mengunjungi Sanur Village Festival mencari informasi di media sosial yang dimiliki dikarenakan Sanur Village Festival mempromokian acara mereka di media sosial seperti Facebook, Instagram dan Twitter. Untuk pernyataan yang lain masing-masing mendapatkan nilai skor 4,02 
untuk pernyataan tertarik untuk membeli produk yang dijual di festival, nilai skor rata rata sebesar 4,09 untuk pernyataan merekomendasikan festival kepada keluarga dan orang terdekat, nilai skor rata rata sebesar 3,51 untuk pernyataan menyebarkan informasi/mengunggah foto-foto mengenai Sanur Village Festival ke media sosial yang dimiliki, nilai skor rata rata sebesar 4,02 untuk pernyataan menjadikan festival sebagai prioritas kunjungan setiap tahunnya.

\section{Hasil Pengujian Instrumen}

Dalam variabel brand image terdapat 10 pernyataan, 14 pernyataan pada variabel morivasi dan 8 pernyataan pada variabel minat berkunjung. 32 indikator pernyataan tersebut telah dijawab oleh 160 orang responden dan selanjutnya dikorelasikan dengan nilai total menggunakan analisis SPSS 25 didapakan hasil bahwa nilai korelasi setiap item pernyataan yang bernilai positif dan besarnya lebih dari 0.30 .

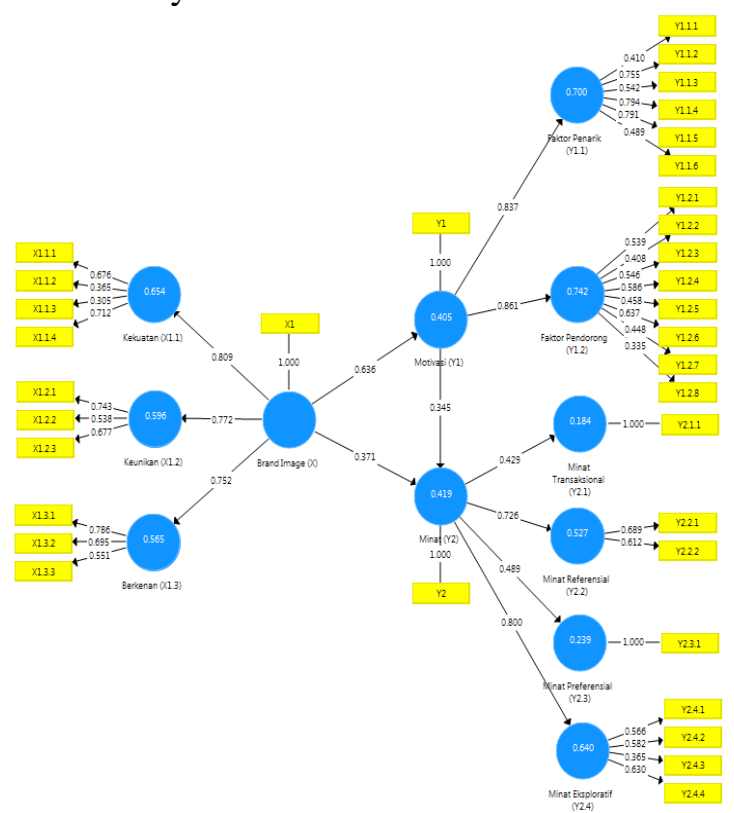

Gambar 1. Hasil Alhorithm Outer Model

Dalam pengujian outer model bertujuan untuk melihat validity dan realiblity contruct suatu model. Analisis pengujian ini akan dilihat daari pengaruh factor loading, average variance extracted (AVE), dan Discriminat validity, serta composite reliability. Variabel brand image, motivasi dan minat memiliki beberapa indikator yang harus dihapuskan dari model karena nilai faktor loadingnya $<0,7$ yaitu X1.1.2 produk yang ditawarkan saat festival bervariasi $(0,365)$, dan X1.1.3 pengemasan festival yang menarik dan inovatif $(0,305)$. Pada variabel motivasi, beberapa indikator yang harus dihapuskan adalah Y1.1.1 mengunjungi Sanur Village Festival untuk keluar dari rutinitas seharihari/relaksasi (0,410), Y1.1.6. mengunjungi Sanur Village Festival untuk merealisasikan keinginan untuk mengunjungi $(0,489)$, Y1.2.2 Atraksi yang dapat dinikmati semua umur (0,408), Y1.2.5 Direkomendasikan oleh teman/keluarga (0,458), Y1.2.7 Sanur Village Festival selalu terjadwal sehingga memudahkan dalam mengatur waktu $(0,448)$, dan Y1.2.8 Sanur Village Festival diselenggarakan bertepatan dengan waktu liburan (0,335). Sedangkan pada variabel minat, beberapa indikator yang harus dihapuskan adalah Y2.4.3 mencari tahu pengalaman kunjungan ke festival melalui teman yang sudah berkunjung $(0,365)$. Setelah terdapat beberapa indikator manifest yang dieliminasi maka akan terbentuk model pengaruh baru.

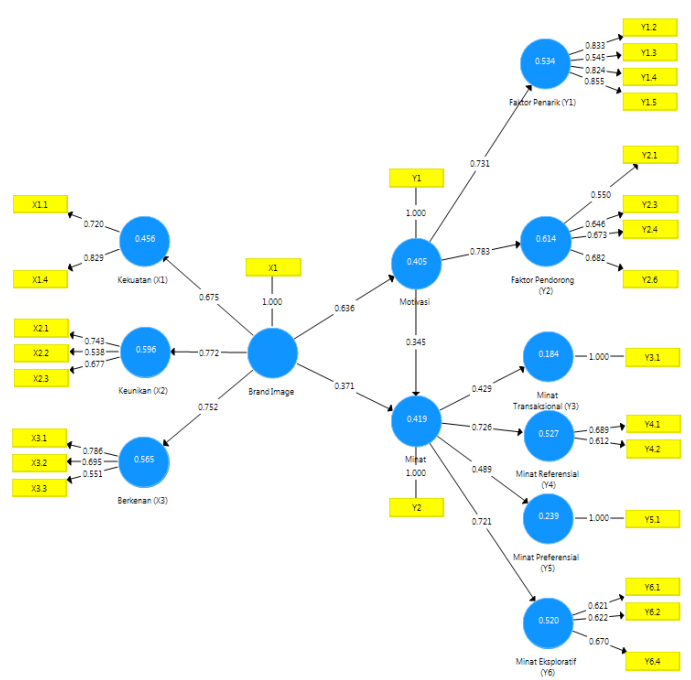

Gambar 2. Hasil Alhorithm Outer Model

Menurut Chin seperti yang dikutip oleh Imam Ghozali, nilai outer loading antara 0,5 0,6 sudah dianggap cukup untuk memenuhi syarat convergent validity. Data $\mathrm{di}$ atas menunjukkan tidak ada indikator variabel yang nilai outer loading-nya di bawah 0,5 , sehingga semua indikator dinyatakan layak atau valid untuk digunakan penelitian dan dapat digunakan untuk analisis lebih lanjut.

Sedangkan nilai AVE sudah memenuhi syarat yaitu $>0,5$ untuk semua konstruk yang terdapat pada model penelitian. Nilai terendah AVE adalah sebesar 0,525 pada konstruk 
(Y2.2) Minat Referensial, hal ini dikarenakan banyaknya indikator yang dikeluarkan untuk memenuhi syarat analisis pada analisis sebelumnya. Sedangkan nilai tertinggi AVE adalah sebesar 1,000 pada konstruk (X) Brand Image, (Y1) Motivasi, (Y2) Minat, (Y2.1) Minat Transaksional, (Y2.3) Minat Preferensial.

Pada discriminant validity ditemukan hasil bahwa masing-masing indikator pada variabel penelitian memiliki nilai cross loading terbesar pada variabel yang dibentuknya dibandingkan dengan nilai cross loading pada variabel lainnya. Hal ini menunjukkan adanya discriminant validity yang baik oleh karena nilai korelasi indikator terhadap konstruknya lebih tinggi dibandingkan nilai kolerasi indikator dengan konstruk lainnya. Jadi berdasarkan hasil yang diperoleh tersebut, dapat dinyatakan bahwa indikator-indikator yang digunakan dalam penelitian ini telah memiliki discriminant validity yang baik dalam menyusun variabelnya masing-masing.

Nilai composite reliability untuk semua konstruk adalah > 0,7. Hal ini menunjukkan bahwa semua konstruk pada model yang diestimasi sudah memenuhi kriteria discriminant validity. Nilai composite reliability yang terendah sebesar 0,721 pada konstruk Kekuatan (X1.1), dan kontruk yang memiliki konsistensi tertinggi terdapat pada konstruk Brand Image (X), Motivasi (Y1), Minat (Y2), Minat Preferensial (Y2.3).

Goodness of fit pada PLS dapat diketahui dengan nilai Q2. Nilai Q2 memiliki arti yang sama dengan koefisien determinasi ( $R$-Square) dalam analisis regresi, yaitu : (1) Nilai $\mathrm{R}$ square dari Brand Image terhadap Motivasi wisatawan domestik berkunjung ke Sanur Village Festival adalah 40,5\%. (2) Nilai $\mathrm{R}$ square dari Brand Image terhadap Minat wisatawan domestik berkunjung ke Sanur Village Festival adalah 41,9\%.

Pengaruh tidak langsung (indirect effect) maksudnya adalah pengaruh dari suatu variabel exogenous terhadap variabel endogenous devendent melalui variabel endogenous entervening. Sedangkan total pengaruh (total effect) adalah hasil penjumlahan pengaruh langsung dan pengaruh tidak langsung. Berdasarkan hasil analisis yang dilakukan, maka besarnya Indirect Effect brand image terhadap minat dengan dimediasi motivasi wisatawan domestik berkunjung ke
Sanur Village Festival sebesar 0,322. Sedangkan total effect antar variabel yang dihasilkan dalam model dan hasil penelitian adalah total pengaruh brand image terhadap minat dengan dimediasi motivasi sebesar 0,498 yang merupakan penjumlahan dari direct effect + indirect effect .

Pengaruh variabel mediasi motivasi kepada variabel independen brand image dan variabel dependen minat menunjukan hasil mengenai jenis variabel mediasi. Pengaruh brand image terhadap minat sebelum dimediasi oleh motivasi menunjukan hasil yang signifikan positif, dan setelah dipengaruhi variabel mediasi minat, hubungan variabel brand image terhadap minat tetap signifikan positif. Dapat disimpulkan bahwa motivasi dalam hipotesis kedua ini adalah Partial Mediation.

Berdasarkan hasil-hasil analisis tersebut dapat disimpulkan bahwa motivasi berpengaruh terhadap minat, dengan motivasi sebagai variabel intervening antara brand image dengan minat.

\section{Pengaruh Pengaruh Brand Image Terhadap Motivasi Wisatawan Domestik Berkunjung ke Sanur Village Festival}

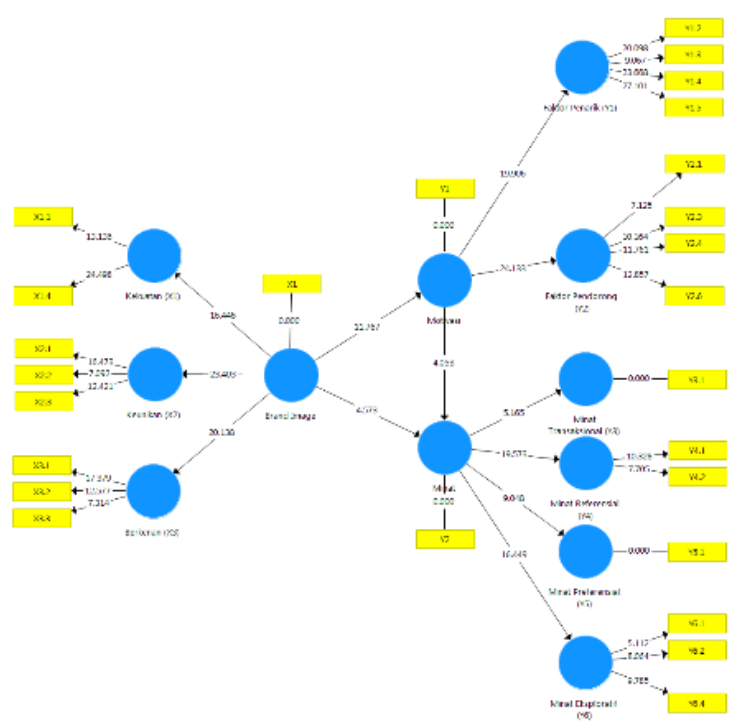

Gambar 3. Uji Hipotesis (Hasil Bootstrapping)

Nilai $t$-statistic pengaruh brand image (X) terhadap motivasi (Y1) wisatawan domestik berkunjung ke Sanur Village Festival adalah sebesar 11,767 > t-Tabel 1,654. Dengan nilai signifikansi sebesar $0,000<0,05$. Hal ini menunjukkan bahwa variabel brand image (X) 
berpengaruh signifikan terhadap motivasi (Y1) dikarenakan nilai t-hitung melebihi nilai $\mathrm{t}$ Tabel. Hal ini disebabkan karena brand image dari Sanur Village Festival dapat memotivasi wisatawan untuk berkunjung ke Sanur Village Festival, baik dilihat dari keunikan atraksi wisata yang ditampilkan, produk yang ditawarkan seperti makanan dan minuman bervariasi yang melibatkan beberapa hotel dan restoran terkenal di Bali, serta keunikan tema yang diangkat setiap tahunnya.

Hasil penelitian ini didukung penelitian dari Wahyuni (2017) yang menyatakan bahwa brand image berpengaruh positif dan signifikan terhadap motivasi. Wisatawan yang terbiasa mengunjungi merek tertentu cenderung memiliki konsistensi terhadap citra (image) dari merek tersebut. Maka dapat dikatakan dengan brand image yang baik dapat mengarahkan pada motivasi berkunjung terhadap suatu merek. Sehingga pengunjung terpengaruh untuk menggunakan barang atau jasa tersebut. Sangat penting bagi Yayasan Pembangunan Sanur selaku pengelola dari Sanur Village Festival dalam membangun brand image yang dihasilkan. Menciptakan brand image tersebut agar dapat berkembang menjadi kuat dipasaran dan semakin memotivasi pengunjung untuk menggunakan produk atau jasa yang ditawarkan. Sehingga pengunjung yang berkunjung menggunakan barang dan jasa bukan lagi karna kebutuhan pokok tapi karena kebutuhan akan aktualisasi.

Menurut (Kotler, 2002) brand Image adalah sekumpulan asosiasi merek yang terbentuk dan melekat di benak konsumen. Konsumen yang terbiasa menggunakan merek tertentu cenderung memiliki konsistensi terhadap brand image. Hal tersebut membuktikan bahwa brand image dari Sanur Village Festival mampu meningkatan kunjungan wisatawan setiap tahunnya, dengan keunikannya menggabungkan kegiatan berskala besar yang melibatkan festival makanan, pameran ekonomi kreatif, serangkaian kontes dan kompetisi, atraksi seni dan budaya, musik, serta berbagai kegiatan yang ramah lingkungan dalam satu acara sehingga dapat memotivasi wisatawan yang ingin berkunjung ke Sanur Village Festival.

\section{Pengaruh Pengaruh Brand Image Terhadap Minat Wisatawan Domestik Berkunjung ke Sanur Village Festival}

Nilai $t$-statistic pengaruh brand image (X) terhadap minat (Y2) tiket kereta api oleh wisatawan domestik yang berkunjung ke Sanur Village Festival adalah sebesar 4,573 > t-Tabel 1,654. Hal ini menunjukkan bahwa variabel brand image (X) berpengaruh signifikan terhadap minat (Y2) dikarenakan nilai t-hitung melebihi nilai t-Tabel. Karena brand image dari Sanur Village Festival mempengaruhi minat wisatawan untuk berkunjung ke Sanur Village Festival hal ini disebabkan oleh waktu diadakannya Sanur Village Festival bertepatan dengan waktu liburan serta didukung dengan menariknya promosi Sanur Village Festival di media sosial seperti Instagram, Facebook dan Twitter.

Hasil penelitian ini didukung penelitian dari Wiratnyana (2014) yang menyatakan bahwa brand image berpengaruh positif dan signifikan terhadap minat. Perkembangan pasar yang sedemikian pesat mendorong wisatawan untuk lebih memperhatikan citra merek (brand image) dibandingkan karakteristik fisik suatu produk dalam memutuskan suatu pembelian atau melakukan kunjungan ke tempat wisata.

Menurut (Kotler, 2002) brand image merupakan suatu kondisi yang dimiliki oleh produk bila ditinjau dari segi sosial dan psikologi dimana konsumen memiliki perasaan dan gagasan tentang merek yang bersifat krusial terhadap konsumen dalam menentukan pilihannya. Sanur Village Festival menggunakan tema yang berbeda - beda setiap tahunnya untuk menarik wisatawan, hal tersebut berdampak pada minat wisatawan dalam menentukan keputusan untuk berkunjung ke Sanur Village Festival tanpa disadari secara tidak langsung wisatawan mencari tahu informasi mengenai Sanur Village Festival serta mencari tahu pengalaman kunjungan ke Sanur Village Festival melalui teman atau keluarga yang sudah pernah berkunjung.

\section{Pengaruh Pengaruh Motivasi Terhadap Minat Wisatawan Domestik Berkunjung ke Sanur Village Festival}

Nilai t-statistic pengaruh motivasi (Y1) terhadap minat (Y2) tiket kereta api oleh wisatawan domestik yang berkunjung ke Sanur Village Festival adalah sebesar 4,053 > 
t-Tabel 1,654. Hal ini menunjukkan bahwa variabel motivasi (Y1) berpengaruh signifikan terhadap minat (Y2) dikarenakan nilai t-hitung melebihi nilai t-Tabel. Hal ini disebabkan karena Sanur Village Festival sangat kreatif mengemas perlombaan, food court, dan atraksi tradisional maupun modern menjadi satu kesatuan acara yang memiliki tema yang berbeda setiap tahunnya sehingga wisatawan dapat memilih apa yang menjadi kebutuhanya serta termotivasi dan berminat untuk berkunjung ke Sanur Village Festival.

Hasil penelitian ini mendukung penelitian dari Favian (2017) yang menyatakan bahwa motivasi berpengaruh positif dan signifikan terhadap minat. Motivasi merupakan hal yang sangat mendasar dalam studi tentang wisatawan dan pariwisata, karena motivasi merupakan sebab dari proses perjalanan wisata, walaupun motivasi terkadang tidak disadari secara penuh oleh wisatawan itu sendiri. Hal ini menunjukkan semakin tinggi motivasi wisatawan maka semakin tinggi pula minat berkunjung wisatawan.

Menurut Pitana dan Gayatri (2005), menyebutkan bahwa "keputusan seseorang untuk melakukan perjalanan wisata dipengaruhi oleh kuatnya push factor dan pull factor. Faktor pendorong umumnya bersifat sosial-psikologis, atau merupakan motivasi dari individu itu sendiri, sedangkan faktor penarik merupakan motivasi dari destinasi tujuan wisata." Sanur Village Festival diselenggarakan untuk wisatawan yang ingin keluar sejenak dari rutinitas sehari - hari, bersenang - senang hingga mempelajari seni budaya tradisional maupun modern yang dipertujukkan saat festival berlangsung dengan didukung variasi atraksi yang ditampilkan menarik dan dapat dinikmati semua umur, hal tersebut mampu memotivasi wisatawan untuk berminat berkunjung ke Sanur Village Festival.

\section{SIMPULAN DAN SARAN Simpulan}

Berdasarkan hasil analisis data dan pembahasan yang telah diuraikan terkait pengaruh brand image terhadap motivasi dan minat wisatawan domestik berkunjung ke Sanur Village Festival, maka dapat diambil simpulan bahwa variabel brand image berpengaruh positif terhadap motivasi wisatawan domestik berkunjung ke Sanur
Village Festival. Hal ini dapat dilihat dari hasil analisis Partial Least Square diperoleh $t$ statistic pengaruh brand image $(\mathrm{X})$ terhadap motivasi (Y1) wisatawan domestik berkunjung ke Sanur Village Festival adalah sebesar $11,767>$ t-Tabel 1,654. Selanjutnya dapat dilihat dari hasil analisis determinasi pengaruh brand image terhadap motivasi wisatawan domestik berkunjung ke Sanur Village Festival diperoleh nilai 40,5\%. Hasil analisis determinasi menunjukkan bahwa variabel bebas mempengaruhi variabel terikat sebesar $40,5 \%$, sedangkan sisanya $59,5 \%$ dipengaruhi oleh variabel lain yang tidak termasuk dalam penelitian ini.

Variabel brand image berpengaruh positif terhadap minat wisatawan domestik berkunjung ke Sanur Village Festival. Hal ini dapat dilihat dari hasil analisis Partial Least Square diperoleh $t$-statistic pengaruh brand image (X) terhadap minat (Y2) wisatawan domestik berkunjung ke Sanur Village Festival adalah sebesar 4,573 > t-Tabel 1,654. Selanjutnya dapat dilihat dari hasil analisis determinasi pengaruh Brand Image terhadap minat wisatawan domestik berkunjung ke Sanur Village Festival adalah 41,9\%. Hasil analisis determinasi menunjukkan bahwa variabel bebas mempengaruhi variabel terikat sebesar $41,9 \%$, sedangkan sisanya $58,1 \%$ dipengaruhi oleh variabel lain yang tidak termasuk dalam penelitian ini.

Variabel motivasi berpengaruh positif terhadap minat wisatawan domestik berkunjung ke Sanur Village Festival. Hal ini dapat dilihat dari hasil analisis Partial Least Square diperoleh $t$-statistic pengaruh motivasi (Y1) terhadap minat (Y2) wisatawan domestik berkunjung ke Sanur Village Festival adalah sebesar 4,053 > t-Tabel 1,654.

\section{Saran}

Berdasarkan hasil dari pembahasan dalam penelitian ini, maka saran yang dapat direkomendasikan kepada pemerintah dapat mengadakan press conference bersama Yayasan Pembangunan Sanur agar festival berjalan sesuai dengan rencana dan dapat meningkatkan kunjungan wisatawan setiap tahunnya. Sedangkan untuk praktisi, Sanur Village Festival mampu menjadi salah satu festival terbesar dan terlengkap dengan cara membuat tema sesuai dengan selera kaum milenial saat ini karena sesuai dengan karakteristik wisatawan dalam penelitian ini 
yaitu sangat banyak berumur 21 sampai 30 tahun. Sanur Village Festival perlu memasang baliho dan spanduk ditempat yang lebih strategis seperti di persimpangan jalan raya disepanjang daerah sanur, sesetan, renon agar dapat dilihat dengan seksama oleh calon pengunjung serta didukung dengan menariknya promosi di media sosial karena melihat banyaknya wisatawan domestik dengan status pelajar (milenial) yang sudah pernah berkunjung ke Sanur Village Festival. Sanur Village Festival menjadi festival yang banyak dinanti oleh wisatawan dengan cara menyediakan wadah saran dari wisatawan yang pernah berkunjung ke Sanur Village Festival untuk kedepannya apa yang harus ditingkatkan. Sedangkan untuk peneliti lain dapat dijadikan referensi tambahan atau acuan dan untuk penelitian selanjutnya perlu ada penelitian lebih lanjut terkait dengan strategi dalam meningkatkan minat wisatawan domestik berkunjung ke Sanur Village Festival, melihat pengaruh brand image terhadap minat dan pengaruh motivasi terhadap minat wisatawan domestik berkunjung ke Sanur Village Festival. 


\section{Kepustakaan}

Andi Supangat. 2007. Statistika dalam Kajian Deskriftif, Inferensi dan Nonparametrik. Edisi Pertama. Jakarta: Kencana Prenada Media Group

Anwar. 2011. Impact of Brand Image, Trust and Affect on Consumer Brand Extension Attitude: The Mediating Role of Brand Loyalty. International Journal of Economics and Management Sciences Vol. 1, No. 5, 2011

Arumni, Klementin Vida. 2013. Pengaruh Gaya Hidup Brand Minded dan Peran Kelompok Acuan Terhadap Minat Beli Produk Smartphone Samsung Berbasis Android. Yogyakarta : Universitas Sanata Dharma.

Chusnul. 2016. Pengaruh Relationship Marketing dan Brand Image Terhadap Kepuasan Pelanggan (Survei terhadap pelanggan Indihome PT. Telkom, Tbk. STO Klojen Malang). Jurnal Administrasi Bisnis (JAB) Vol. 3 No. 8
Cooper, Donald R., dan Pamela, S. Schindler. 2006. Metode Riset Bisnis, Volume 1. PT Media Global Edukasi. Jakarta.

Ferdinand, Augusty. 2002. Pengembangan Minat Beli Merek Ekstensi. Semarang : Badan Penerbit Universitas Diponegoro

Gumilar. 2015. Pengaruh Perubahan Elemen Fisik Brand Terhadap Citra Merek (Studi Pada Konsumen PT. Citilink Indonesia Tbk). Malang : Universitas Brawijaya.

Hartono, J and Willy Abdullah, 2009. Konsep \& aplikasi PLS untuk penelitian EMpiris. Yogyakarta: BPFE.

Wachyuni. 2017. Pengaruh Brand Image Terhadap Motivasi Berkunjung Tamu Di Sushi Tei Restaurant Pondok Indah Mall Jakarta. Jakarta : Jurnal Sains Terapan Pariwisata.

Wiratnaya. 2014. Pengaruh Citra Merek Terhadap Minat Beli Wisatawan pada Komaneka Resorts \& Spa Group di Kawasan Pariwisata Ubud, Gianyar. Denpasar : Jurnal Ilmiah Hospitality Management 